\title{
NATURAL REPRODUCTION ON ABANDONED LAND
}

\author{
By R. G. RAY \\ Dominion Forest Service
}

W HEN the Petawawa Military Area was acquired by the Dominion Government in 1914, it included a number of scattered areas which had been cleared and cultivated for farming. The former owners were bought out, the land was abandoned, and the ground has remained covered with a thick mat of grass, occasionally interrupted by shrubs. Although these areas are surrounded by woods yielding an adequate supply of seed, the process of returning to the natural condition has been decidedly slow. $\mathrm{Ob}$ stacles in the way of germination are evidently too great to allow seedlings to become established, unaided, within a reasonable time.

A part of this abandoned land has been planted for experimental and demonstration purposes; smaller sections have been reserved for studies in natural reproduction under various methods of treatment, and a number of permanent sample plots have been established within the last ten years to record the results. To illustrate one of these studies, the data which have been obtained from a series of three plots will be cited in this article.

This area, about ten acres in size, is bordered by mixedwood; softwood; but chiefly by mature hardwoods containing scattered white pine, spruce, and balsam fir seed-trees. Conditions here differ from those encountered on other similar areas, in that a part of the land was ploughed and left in this condition, whereas other sections are merely abandoned pastures. The importance of this will be illustrated later.

\section{METHODS OF STUDY}

Three permanent sample plots, each less than half an acre in size, were established in the spring of 1924 . Their positions with respect to the surrounding forest and to one another may be seen on the map.

On each plot all coniferous seedlings were staked and numbered with aluminium tags. A map was then made of the plot showing the number and location of each seedling. Heights of all seedlings were measured, and notes were taken on their general condition. Thus a permanent record was estab. lished for each seedling.

In addition, a study was made of ground-cover and underbrush in the autumn of 1931, from mechanically selected subplots, five on each plot. Since this is a comparatively new phase, nothing but present conditions can be shown.

Each plot represents a different set of conditions. No. 48 was intended as a study of competition between hardwood and conifer seedlings, but owing 


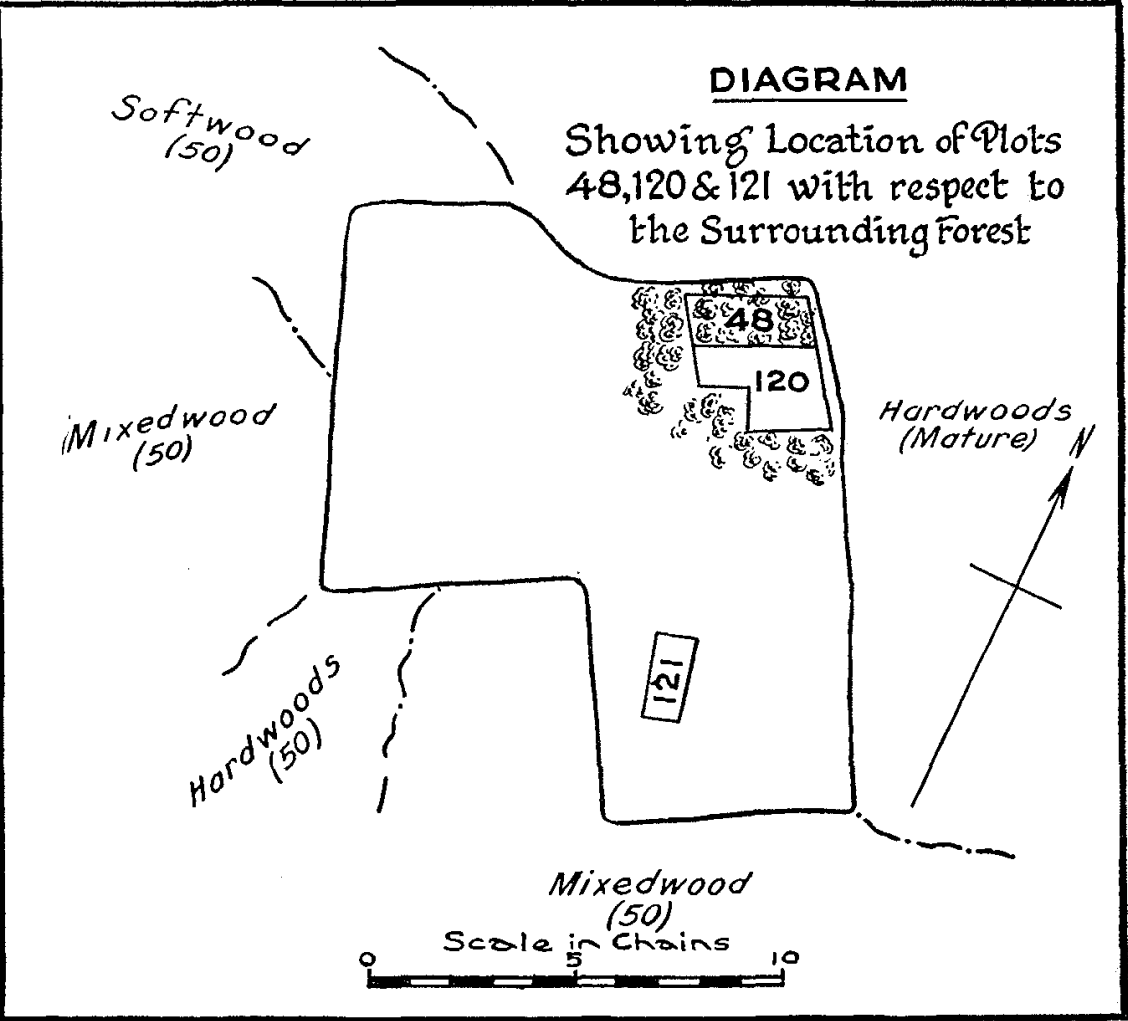

to a rapid, healthy growth of white birch, it has now the appearance of a pure hardwood stand. Although hardwoods and softwoods started at the same time, the birch now measures 2 inches or 3 inches D.B.H., while only eleven conifers (all balsam fir) have reached the sapling stage with an average D.B.H. of 0.7 inch.

Plot No. 120, which is adjacent to 48 , shows the effect of a sudden release from competition. In 1924, when the plots were laid out and when the growth was approximately eight years old, all hardwoods were cut back, and none have become established since then. This fact in itself is significant. On both of these plots, the soil had been ploughed up when the farm was abandoned, and a stand of mixedwood was soon established. Several years later, when the furrows became matted with grass, hardwoods ceased to take root altogether, while conifers met with only partial success. Thus the one cutting of hardwoods on plot 120 has had a permanent effect.

The origin of Plot No. 121 is slightly different. The land was not in a ploughed state when abandoned, and the seed supply may have been better. (See map). 
Soil conditions are the same for all three plots, namely, a well drained sandy loam of moderate depth. Along the eastern border of each plot, especially of Nos. 120 and 121, the level of the ground is slightly depressed, more moisture is available and a growth of underbrush (alder) has taken possession. This is quite dense on No. 121, and, as will be seen, it has a considerable effect on the establishment and growth of seedlings. The effect of this local moisture on No. 48 is to produce numbers of hard maple seedlings beneath the birch, while what little underbrush exists is kept down by the birch overstory.

In general, the experiment embraces three aspects of seedling growth:

(1) In severe competition with intolerant hardwoods. (Plot 48).

(2) After sudden release from all hardwood competition. (Plot 120).

(3) Without competition and with no original treatment of the site. (Plot 121).

\section{TABLES AND OBSERVATIONS}

The remeasurement in 1931 produced some interesting figures which have been compiled in tabular form, showing the developments of the last eight years. Before citing these figures, a brief description of general conditions on each plot may be desirable.

The stunted appearance and slow growth of conifer seedlings on Plot No. 48 show only too clearly the results of suppression by the overstory of white birch. Further, rabbits with an appetite for tops and tender shoots have severely damaged a large number of seedlings, particularly white pine, Extreme cases include height measurements which are less now than they were eight years ago. The remarkable part is that so many of the damaged seedlings have survived.

The open character of No. 120 has produced rapid height growth with poorer stocking. Rabbit activities have not been severe, but the white pine weevil has seriously damaged most of the larger white pine.

No. 121 combines the main features of the other two plots. The area covered with underbrush corresponds to the suppressed condition on No. 48, while the rest of the plot is similar to No. 120 . By far the greater majority of seedlings are to be found beneath the underbrush, although it covers only about 40 per cent of the plot. 
TABLE I.

Number of Seedlings per Acre, with their average heights 1924

\begin{tabular}{|c|c|c|c|c|c|c|}
\hline \multirow[t]{2}{*}{ Species } & \multicolumn{2}{|c|}{ Plot 48} & \multicolumn{2}{|c|}{ Plot 120} & \multicolumn{2}{|c|}{ Plot 121} \\
\hline & No. & $\begin{array}{c}\text { Height } \\
\text { Feet }\end{array}$ & No. & $\underset{\text { Feet }}{\text { Height }}$ & No. & $\underset{\text { Feet }}{\text { Height }}$ \\
\hline \multirow{7}{*}{$\begin{array}{l}\text { White Pine } \\
\text { Red Pine } \\
\text { Spruce } \\
\text { Balsam Fir } \\
\text { Cedar } \\
\text { Larch } \\
\text { Hemlock }\end{array}$} & 763 & 0.5 & 181 & 0.6 & 346 & 1.1 \\
\hline & 5 & 1.7 & & & $\ldots$ & \\
\hline & 15 & 0.4 & 39 & 0.9 & 75 & 1.0 \\
\hline & 384 & 1.3 & 370 & 1.4 & 940 & 0.6 \\
\hline & 2 & 0.7 & $\ldots$ & $\ddot{0}$ & $\cdots$ & $\ddot{i} \ddot{7}$ \\
\hline & $\ldots$ & & 2 & 4.0 & 3 & 1.7 \\
\hline & 2 & 1.2 & $\ldots$ & $\cdots$ & $\cdots$ & $\cdots$ \\
\hline TOTAL & 1170 & 0.8 & 592 & 1.1 & 1360 & 0.7 \\
\hline
\end{tabular}

TABLE II.

Number of Seedlings per acre: Average Heights 1931

\begin{tabular}{|c|c|c|c|c|c|c|}
\hline \multirow[t]{2}{*}{ Species } & \multicolumn{2}{|c|}{ Plot 48} & \multicolumn{2}{|c|}{ Plot 120} & \multicolumn{2}{|c|}{ Plot 121} \\
\hline & No. & $\begin{array}{c}\text { Height } \\
\text { Feet }\end{array}$ & No. & $\begin{array}{c}\text { Height } \\
\text { Feet }\end{array}$ & No. & $\begin{array}{c}\text { Height } \\
\text { Feet }\end{array}$ \\
\hline White Pine & 755 & 0.9 & 346 & 2.6 & 298 & 3.1 \\
\hline Red Pine & 2 & 0.8 & $\ldots$ & $\ldots$ & 4 & 2.1 \\
\hline Spruce & 30 & 0.8 & 29 & 3.0 & 71 & 3.5 \\
\hline Balsam Fir & 378 & 2.5 & 294 & 3.9 & 940 & 2.7 \\
\hline Cedar & 2 & 0.8 & $\ldots$ & $\ldots$ & $\ldots$ & $\ldots$ \\
\hline Hemlock & 2 & 2.8 & $\ldots$ & $\ldots$ & $\ldots$ & $\cdots$ \\
\hline TOTAL & 1170 & 1.4 & 669 & 3.2 & 1310 & 2.8 \\
\hline
\end{tabular}

TABLE III.

Sapling Stand Table

Numbers Per Acre ( 1 " to $3^{\prime \prime}$ D.B.H.) and Volume in Cubic Feet 1931

\begin{tabular}{|c|c|c|c|c|c|c|}
\hline & \multicolumn{2}{|c|}{ Plot 48} & \multicolumn{2}{|c|}{ Plot 120} & \multicolumn{2}{|c|}{ Plot 121} \\
\hline & No. & Volume & No. & Volume & No. & Volume \\
\hline $\begin{array}{l}\text { White Pine } \\
\text { Spruce } \\
\text { Balsam Fir } \\
\text { Larch }\end{array}$ & $\begin{array}{l}\cdots \\
27 \\
\cdots\end{array}$ & $\begin{array}{l}\text { Cu. Ft. } \\
\ldots \ldots \\
\ldots \ldots \\
0.996 \\
\ldots \ldots\end{array}$ & $\begin{array}{r}17 \\
7 \\
76 \\
2\end{array}$ & $\begin{array}{l}\text { Cu. Ft. } \\
0.686 \\
1.360 \\
3.040 \\
0.128\end{array}$ & $\begin{array}{r}168 \\
11 \\
105 \\
4\end{array}$ & $\begin{array}{c}\mathrm{Cu} . \mathrm{Ft} . \\
13.20 \\
0.56 \\
6.54 \\
0.22\end{array}$ \\
\hline Total & 27 & 0.996 & 102 & 5.214 & 288 & 20.52 \\
\hline
\end{tabular}

Tables I., II., and III. show the numbers of seedlings by species, with their average heights for the years 1924 and 1931. The principal species are clearly white pine and balsam fir; of the others, spruce alone is entitled to consideration. No marked variation in average heights for 1924 occurs; the 
marked variations shown in the 1931 figures would indicate unequal growth factors.

Since it is now necessary to distinguish seedlings from saplings, separate tables were made for each (II. and III.). Therefore, Tables I. and II. cannot be directly compared.

From Tables I., II., and III., the net increase in stocking points favourably to the open plots. The actual figures are 27, 178, and 238 per acre for plots 48,120 , and 121 respectively.

The numbers of saplings given in Table III. indicate a fair idea of the growth on each plot. As can be expected, plots 120 and 121 are far in advance of plot 48 in this respect also.

TABLE IV.

New Growth (1925-1931)

Seedlings Per Acre and Average Heights

\begin{tabular}{|c|c|c|c|c|c|c|}
\hline & \multicolumn{2}{|c|}{ Plot 48} & \multicolumn{2}{|c|}{ Plot 120} & \multicolumn{2}{|c|}{ Plot 121} \\
\hline & No. & Height & No. & Height & No. & Height \\
\hline $\begin{array}{l}\text { White Pine } \\
\text { Red Pine }\end{array}$ & 214 & $\begin{array}{c}\text { Feet } \\
0.7\end{array}$ & 210 & $\begin{array}{c}\text { Feet } \\
1.3\end{array}$ & $\begin{array}{r}153 \\
4\end{array}$ & $\begin{array}{c}\text { Feet } \\
2.2 \\
2.1\end{array}$ \\
\hline $\begin{array}{l}\text { Spruce } \\
\text { Balsam Fir }\end{array}$ & $\begin{array}{l}17 \\
42\end{array}$ & $\begin{array}{l}0.7 \\
0.9\end{array}$ & $\begin{array}{r}5 \\
37\end{array}$ & $\begin{array}{l}1.6 \\
1.6\end{array}$ & $\begin{array}{r}7 \\
146\end{array}$ & $\begin{array}{l}0.9 \\
1.2\end{array}$ \\
\hline Total & 273 & 0.7 & 252 & 1.4 & 310 & 1.7 \\
\hline
\end{tabular}

New growth, that is, seedlings which have become established since 1924, is listed in Table IV. No. 48 shows a slight advantage over No. 120. Naturally, seedlings become established under a canopy of some sort much more easily than in the open where the ground is covered with grass. This point is further illustrated by the fact that by far the greater proportion of new growth on plots 120 and 121 was found beneath or close to underbrush. This once again demonstrates the unfavorable character of thick grass for the establishment of seedlings.

Plot 121 requires additional explanation. The odd concentration of seedlings on a small part of the plot introduces another factor which is not very important on 120, and still less on 48 . This is moisture. The great increase in balsam fir with a decrease in white pine points to a larger supply of water localized on this small part of the plot.

Growth in height which has taken place since 1924 will be seen in Table $\mathrm{V}$. This includes all seedlings which have survived to the last remeasurement, some of which are now classified as saplings. It will be seen that white pine has derived much more benefit from the release (Plot 120) than either spruce or balsam fir. 
TABLE V.

Height Growth of Reproduction (1924-1931, Inclusive)

\begin{tabular}{|c|c|c|c|c|c|c|c|c|c|}
\hline \multirow[b]{2}{*}{ Species } & \multicolumn{3}{|c|}{ Plot 48} & \multicolumn{3}{|c|}{ Plot 120} & \multicolumn{3}{|c|}{ Plat 121} \\
\hline & $\begin{array}{l}\text { Avera } \\
\text { Heigh } \\
1924 \\
\text { F }\end{array}$ & $\begin{array}{c}1931 \\
\text { et }\end{array}$ & $\begin{array}{l}\text { Mean } \\
\text { Annual } \\
\text { Growth } \\
\text { Feet }\end{array}$ & $\begin{array}{c}\text { Ave } \\
\text { Hei } \\
192\end{array}$ & $\begin{array}{l}\text { age } \\
\text { ht } \\
-1931\end{array}$ & $\begin{array}{l}\text { Mean } \\
\text { Annual } \\
\text { Growth } \\
\text { Feet }\end{array}$ & $\begin{array}{l}\text { Aver } \\
\text { Heig } \\
1924\end{array}$ & $\begin{array}{l}\text { ge } \\
1931\end{array}$ & $\begin{array}{l}\text { Mean } \\
\text { Annual } \\
\text { Growth } \\
\text { Feet }\end{array}$ \\
\hline White Pine & 0.6 & 1.0 & 0.06 & 0.7 & 4.9 & 0.60 & 1.2 & 6.6 & 0.79 \\
\hline Red Pine & 0.3 & 0.8 & .12 & & & & & & $\because$ \\
\hline Spruce & 0.3 & 1.0 & .10 & 1.0 & 5.1 & .59 & 1.0 & 4.7 & .53 \\
\hline Balsam Fir & 1.3 & 3.0 & .24 & 1.1 & 5.2 & .59 & 0.6 & 3.8 & .46 \\
\hline $\begin{array}{l}\text { Cedar } \\
\text { Larch }\end{array}$ & 0.7 & 0.8 & .02 & 4.0 & 10.2 & .90 & 1.8 & 14.3 & 1.80 \\
\hline Hemlock & 1.2 & 2.8 & .23 & $\ldots$ & $\cdots$ & $\cdots$ & $\ldots$ & $\cdots$ & $\ldots$ \\
\hline Average & 0.9 & 1.80 & .13 & 1.0 & 5.1 & 0.6 & 0.8 & 4.5 & 5.2 \\
\hline
\end{tabular}

TABLE VI.

\section{CONDITION OF SEEDLINGS}

PLOT 48

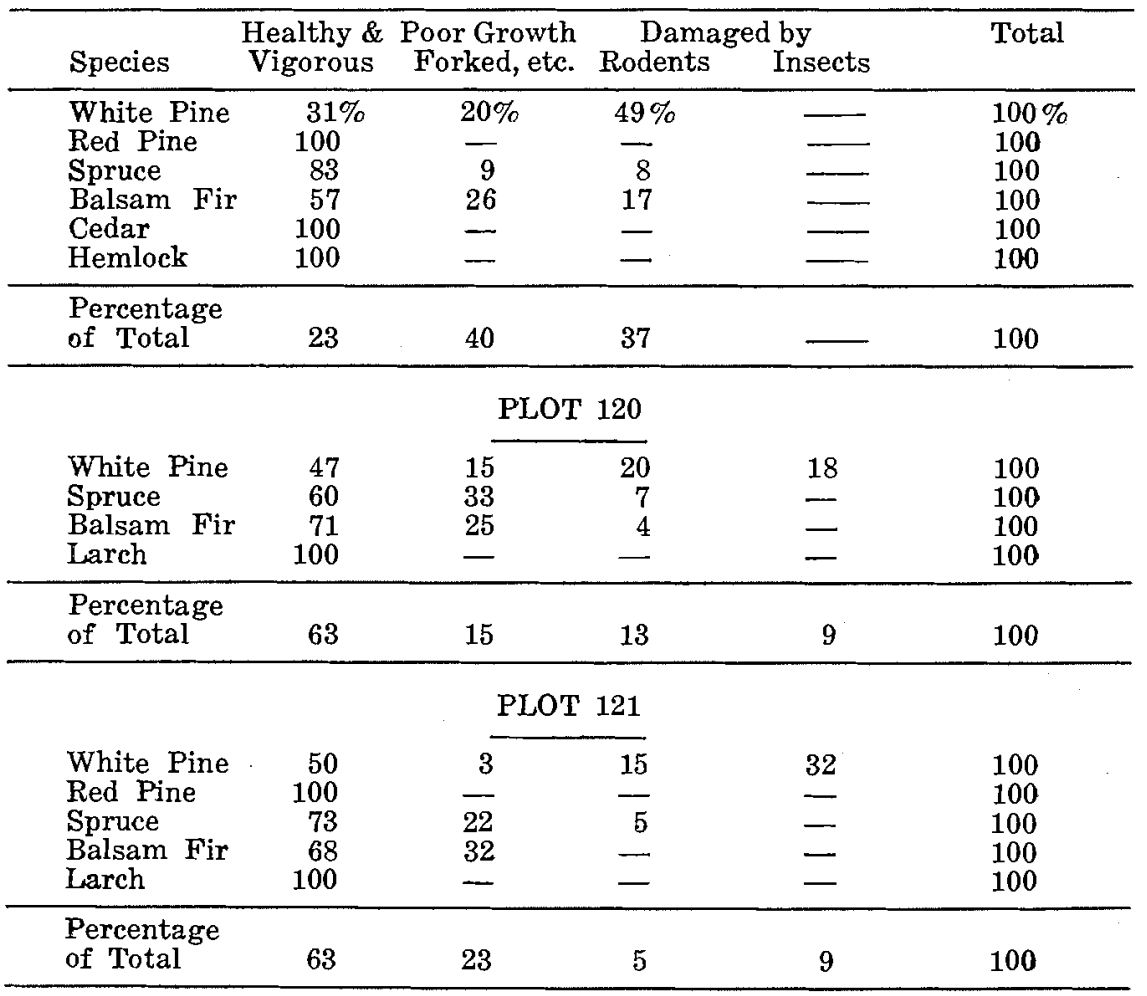


In conjunction with height measurements, notes were recorded on the general condition of each seedling. These are summarized in Table VI. under three headings. The first and third require no explanation. "Poor growth" includes those trees which have an unhealthy appearance, due to severe suppression (by other seedlings, underbrush, etc.), as a result of damages by animals some time ago, or to other causes. It is unfortunate that such widespread damage was caused by animals and insects, because the results of the experiment are certainly influenced by these agencies.

Damage to white pine is the most severe. In fact, it presents rather a hopeless case. Under shade, as is exemplified by plot 48, animals (probably rabbits) chew the tops and tender branches, greatly retarding the growth, and at times causing the death of the seedling. In the open, the more rapid growth apparently reduced this hazard, but at the same time produces favorable conditions for the white pine weevil. The typical dwarfed, bushy specimens, caused by continual killing of the leader, are only too common on plots 120 and 121.

TABLE VII.

Mortality and Net Change, Per Cent

\begin{tabular}{|c|c|c|c|c|c|c|}
\hline Species & $\begin{array}{r}\text { Plot } \\
\text { Mortality } \\
\%\end{array}$ & $\begin{array}{c}48 \\
\text { Net } \\
\text { Change }\end{array}$ & $\begin{array}{c}\text { Plot } \\
\text { Mortality } \\
\%\end{array}$ & $\begin{array}{c}120 \\
\text { Net } \\
\text { Change }\end{array}$ & $\begin{array}{l}\text { Plot } \\
\text { Mortality }\end{array}$ & $\begin{array}{c}121 \\
\text { Net } \\
\text { Change } \\
\%\end{array}$ \\
\hline White Pine & 29 & -1.3 & 16 & 100 & 10 & 34 \\
\hline Red Pine & 50 & -50 & - & - & - & - \\
\hline Spruce & 16 & 100 & 19 & -6.2 & Nil & 10 \\
\hline Basam Fir & 4 & 6.5 & 10 & Unch. & 4 & 11 \\
\hline Cedar & $\mathrm{Nil}$ & Unch. & $\ldots$ & & & \\
\hline Larch & - & - & Nil & Unch. & Nil & Unch. \\
\hline Hemlock & Nil & Unch. & $\longrightarrow$ & - & - & - \\
\hline Average & 17 & 2 & 12 & 30 & 5 & 17 \\
\hline
\end{tabular}

Table VII., showing mortality, indicates the general trend of the young seedling stand. The difference between the numbers of "new growth" and "dead," taken as a percentage of the original total (i.e., for 1924), indicates "net change." Thus, these percentages give a rough idea of the rate of increase or decrease of each species.

The most notable features are the unusually rapid increases of white pine on the open plots and of spruce, in contrast, on the shaded ones. It appears likely, then, from these net-change figures, supplemented by height-growth data from Table V, that the two plots, Nos. 48 and 120 , will eventually be of decidedly different composition,-No. 48 comprising balsam fir, spruce, and white pine (in order of importance of conifers), No. 12 consisting of white pine with scattered balsam fir and spruce. It is probable that No. 48 will 
always contain a large proportion of hardwood, since maple seedlings are becoming established in considerable numbers.

This is not the case at all on the other two plots. The dense cover of grass is evidently more unfavorable to the establishment of hardwoods than to softwoods, with the result that hardwoods are now entirely negligible.

\section{GROUND-COVER AND UNDERBRUSH}

An attempt was made to correlate Cajander's vegetation types with the ground-cover species found on these plots, but without definite success. However, the nearest approach to groups in his classification would indicate a mixed type of forest.

The ground-cover is of the grass-herb class, and is, in general, dense. Grasses form the major part, prominent plant species are few, and mosses and ferns are scanty.

On the eastern sides of the plots, underbrush increases, while the ground. cover shows a corresponding decrease, and, moreover, the proportion of grass is less. Anything which tends to break up the solid cover of grass, such as underbrush and larger plants like golden rod, can be regarded favourably at least in this one respect, that it causes the removal of one of the most serious obstacles to natural reproduction.

The following tables show the distribution and principal species of groundcover and underbrush common to all three plots:-

\section{GROUND.COVER}

Distribution by species, in per cent.

\begin{tabular}{lccc} 
Species & Plot 48 & Plot 120 & Plot 121 \\
\hline Grass (Various species) & 40 & 50 & 60 \\
Golden Rod (Solidago) & 35 & 20 & 15 \\
Vetch (Vicia Cracca) & - & 1 & 15 \\
Other species & 25 & 29 & 10 \\
\hline TOTAL & 100 & 100 & 100 \\
\hline
\end{tabular}

Total number of species represented on one or more of the plots:- 42 .

\section{DENSITY OF GROUND-COVER}

Per cent. of Ground Covered

$\begin{array}{ccc}\text { Plot } 48 & \text { Plot } 120 & \text { Plot } 121 \\ 70 & 90 & 75\end{array}$


UNDERBRUSH

Distribution by Species

Species

Plot 48

Plot 120 Plot 121

Alder (Alnus incana)

Blackberry (Rubus allegheniensis)

Raspberry (Rubus idaeus)

Willow (Salix)

Meadowsweet (Spiraea salicifolia)

Hardhack (Spiraea tomentosa)

\begin{tabular}{rrr}
$\%$ & $\%$ & $\%$ \\
10 & 10 & 40 \\
50 & 40 & 5 \\
25 & 20 & 30 \\
& 20 & 20 \\
15 & 10 & 5 \\
\hline 100 & 100 & 100 \\
\hline
\end{tabular}

Total

DENSITY OF UNDERBRUSH

Percentage of Ground Covered

Plot 48

Plot 120

Plot 121

$15 \%$

$40 \%$

$35 \%$

SUIMMARY

The experiment is still in its early stages, but there are, nevertheless, some definite indications of the final results.

These are as follows:-

1. That a thick cover of grass such as is typical of abandoned land is most unfavorable for the establishment of seedlings, both of hardwoods and softwoods.

2. That where the ground-cover is broken by ploughing, good reproduction can be expected, although it might be largely hardwood.

3. That where other agencies such as trees, underbrush, shrubby plants, etc., break up the solid cover of grass, conditions for the establishment of conifers become favorable.

4. That in the case of an early release cutting (plot 120) white pine reacts much more favorably than either spruce or balsam fir.

5. That, considering the damage to conifers under heavy shade (from animals) and to white pine in the open (weevil), it is most likely that an intermediate condition of shade would be more satisfactory for conifers in general. 